\title{
Work-Life Conflict and Organizational Commitment: A Study Of Female Faculty In Higher Education
}

\author{
Sobia Shujaat \\ Department of Management Sciences \\ Bahria University \\ Iram Tahir \\ Department of Public Administration \\ University of Karachi \\ Akhtar Baloch
Benazir Bhutto Shaheed University
}

\begin{abstract}
This study was conducted to discover the impact of work-life conflict on organizational commitment of female faculty at private universities in Karachi, Pakistan. To test association between the two variables, correlation was used. The results were further corroborated by the use of contingency table. The target population was permanently employed female faculty of private universities. The study was done through interviews and questionnaire survey. The method employed for this purpose wast-test of correlation and chi-square test of association. The study revealed that faculty members at private universities in Karachi had time-based conflict but they did not have strain-based and behaviour-based Conflict. The female faculty were committed to their organizations and the affective commitment showed higher result than continuance and normative commitment. The study reveals that there exists a weak association between two critical variables i.e. work-life conflicts and organizational commitment.
\end{abstract}

Keywords: Work- Life Conflict, Organizational Commitment, Female Faculty.

$$
\begin{aligned}
& \text { تخاخص }
\end{aligned}
$$

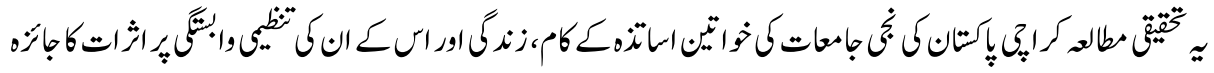

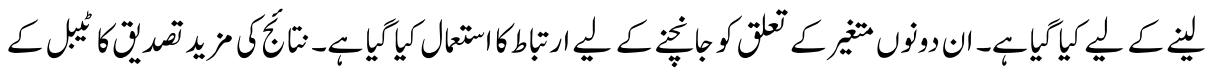

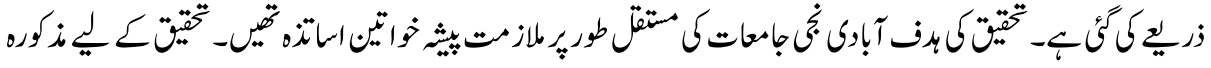

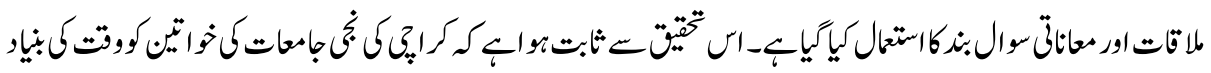

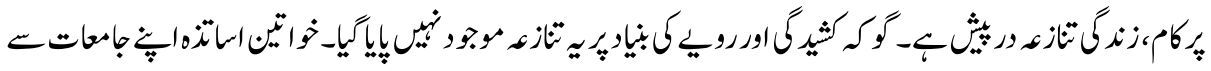




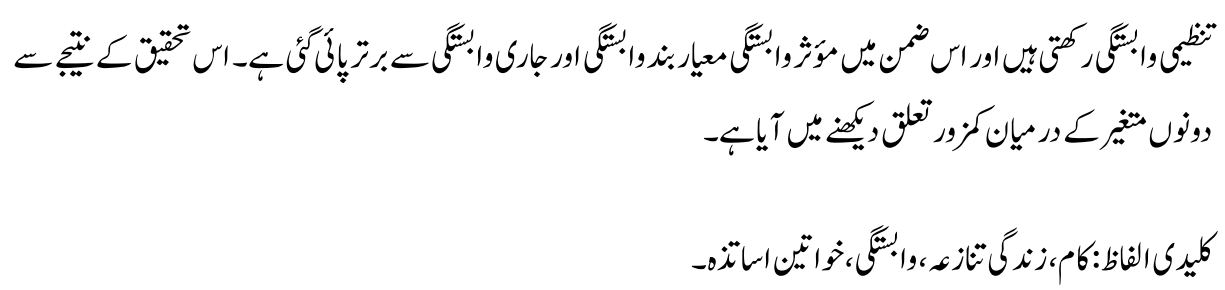

\section{Introduction}

Women are the pillars of every society and contribute equally in the progress and development of any nation. Labor market trends in developing countries have revealed a rising diverse force, showing an increased number of women (Silver and Cynthia, 2000). As per Pakistan's Population Census Organization, females comprise about 49 percent of the total population, of which around 16 percent are a part of country's labor force (2017).Despite working equally with their male counterparts, women around the world still bear the main responsibility for household activity and family care (Greenhaus \& Parasuraman, 1991; Demo \& Acock, 1993). It is essential to understand the work problems that women face as these can have a strong impact on their performance, selfesteem and job satisfaction. For instance, stress is one main outcome of work-life conflict and is negatively associated with absenteeism and dissatisfaction, whereas positively linked to undermine productivity (Tausig, 1999). When a working woman spends more time on paid work, she has to sacrifice time spent on household work and vice versa, resulting in work-life conflicts. Therefore, organizations are developing policies to help employees balance their work-life responsibilities. Parenting is one of the most important activities performed by married working women where as in case of unmarried women in Pakistan, care giving to elders is a core value. Hence, it may be said that work-family conflicts are on-going issues for career-oriented women (Wentling, 1996), and therefore, much research on work and family has been focused on married men and women living with a partner and having children (Parasuraman \& Greenhaus, 2000).

The objectives of this study were to examine the impact of different kinds of work-life conflicts (identified by Netemeyer et al.1996) on types of organizational commitment (defined by Allen and Mayer, 1990) of women in all private universities of Karachi, Pakistan. It also tried to answer which type of conflict has the highest effect on employee commitment, and which type of commitment is stronger among female employees in educational institutes. Another purpose was to find out how strongly work life conflicts are affecting organizational commitment among female employees.

\section{Work-Life Conflict}

This trend of more working women in the workforce has created challenges for both employees and organizations. It has given rise to work-life conflicts. Greenhaus \& 
Beutell (1985) has defined work-life conflict as "A type of inter role conflict in which pressures of one role disturb the balance to perform the other role effectively". It is a multidimensional model comprising of time-based conflict, strain-based conflict and behavior-based conflict. Study revealed that women experience greater distress than men (Menaghan \& Elizabeth, 1989). Studies also show that the number of hours spent on work per week is positively associated with work-family conflict (Burke et al. 1980). As compared to unmarried people, married people experience more work-life conflict and it is anticipated that parents will experience more work-life conflict as compared to those having no children (Herman \& Gyllstrom, 1977). Likewise, studies also show that parents having younger children show more work-life conflict as compared to those parents having older children (Greenhaus \& Kopelman, 1981). Another study revealed that married women employed part-time were likely to have more work life conflict as compared to those who are employed full-time (Hall \& Gordan. 1973). A key determinant of work-life conflict is work stressor. Indications of strain-based conflicts include anger, tension, fatigue, depression and anxiety. When strain is caused at work, it makes it difficult to create harmony at work. Study reveals a positive relationship between conflict at work and work-life conflict (Jones and Butler, 1980).Psychological and physical work demands are also positively associated to work-family conflict (Pleck et al., 1980). Differences in attitudes between husband's and wife's attitude towards wife's employment can also produce stress (Eiswirth-Neems \& Handal, 1978). Behaviorbased conflict is faced when behavior required at one role is shown in another role also where it is not required. Theory proposes that a male employee exhibiting a particular behavioral style at work might be showing the same behavioral style at home which might not be required by members at home (Bruke \& Bradshaw, 1981).

\section{Organizational Commitment}

Organizational effectiveness depends on employee commitment towards goal attainment (Barnard, 1938). Organizational commitment is defined as a psychological bonding between an employee and his organization that makes it difficult for the employee to quit the organization (Allen \& Meyer, 1990). Various studies have been carried out to examine the determinants of organizational commitment and their impact on organizational outcome. Studies indicate that teachers with increased level of commitment outperform their counterparts who lack commitment (Chughtai \& Zafar, 2006). It has been observed that employers who provide flexible sick leave and child care assistance experience reduced turnover (Baughman et al. 2003). Studies also show that female employees encompass higher levels of continuance commitment than men (Stewartet al. 2007). Literature also reveals that those women who perceive that their organizations are offering flexible timing exhibit higher level of organizational commitment (Scanduraet al. 1997). Studies conducted to examine the impact of gender differences on employees' organizational commitment show that women demonstrate 
greater level of normative commitment compare to male employees (Khalili \& Asmawi, 2012). In order to cater to such problems and to improve employee commitment, organizations provide family-friendly benefits such as child-care facilities, flexible work schedules and other benefits through which they can balance work and life (Dessler \& Varkkey 2009; Geisel, 2004; Hannay \& Northam, 2000). Family-friendly benefits may improve performance of those employees who face work-family conflicts, leading to anger among employees which can affect employee performance (Lambert, 2000; Judge et al. 2006). It has also been noted that organizations which offer friendly benefits experience a significant reduction in employee turnover (Baughman et al, 2003).

\section{Pakistan's Situation}

Growth in labor force participation of women is a major cultural trend in Pakistan. However, the percentage is not encouraging, as the male to female worker ratio in Pakistan is 4:1. According to World Bank report Female Labor Force Participation (FLFP) is lowest in Pakistan as compared to developed and South Asian countries. Over the last several years, Pakistan is facing inflation although it is decreasing (Social Policy Development Centre, 2017).One significant reason for the increase in FLFP is high inflation that cannot be managed by a single earner in the family. Pakistan is a developing nation with a distinct culture, and the people are bound to follow their core values. Husband and wives are strongly dependent on each other and major decisions are still taken by the male head of the family. Being a male dominant society, hence the main responsibility of running home affairs lies on a woman and hence she faces more difficulty in balancing professional and personal life.

\section{Literature Review}

Bhagat and Chassie (1981) identified that the best predictor for organizational commitment is satisfaction whereas stress is the second best; however, it is negatively related to organizational commitment. Cockrum \& White (1985) suggested that a higher recognition and legitimization of the single lifestyle would help in eliminating some of the obstacles to social and personal interaction. Trovato \& Vos (1992) examined the relationship in 1971 and then again in 1981, when cultural conditions were significantly different. They tested two hypotheses. One for the year 1971, related to increased suicidal rate among male and female due to married female labor participation, and the other for 1981, related to decreased suicidal rate among male and female due to married female labor participation. The hypotheses were tested using multiple regression (log-linear model) and were proved to be statistically significant. The study indicates that when women take on a more dominant role in the economy, there is less psychological distress among husbands and wives. MacDermid et al. (1994) examined relationship between work-family tension and working conditions by using Ordinary Least Square. Result 
indicates that compared to women in large organizations, the women in small organizations perceived their jobs with more demanding work schedules and significantly lower salaries but unexpectedly greater benefits. Hence, it is suggested that in small organizations the employees are no less in need of help managing work and family demands than large business employees are, and they also experience equal work-family tension. Browne (1998) analysed an evolutionary explanation of women's workplace status through secondary research. It is concluded female are biologically different and so are their characteristics. They have dissimilar priorities from their jobs and so they are rewarded with what they struggle for. Employers prefers employees who work for longer hours, freely travel, and can smoothly move on their career advancement path without extended absences for childbirth. Mothers have stronger bonding with their children as compare to fathers, which suggest that policy makers must keep this tip in mind and so modified benefits need to be provided at work. Konrad \& Mangel (2000) showed that firms employing females in a higher proportion have a strong positive relationship between work-life programs and productivity. The study suggests that organizations that employ higher number of professional/women may benefit from adopting work-family programs. Lamsa \& Sintonen (2001) suggest that new discussions are needed which could challenge the current male dominant discourse that exists in managerial and organizational practices and this requires further study. Schieman et al. (2003) examined if home-to-work conflict is associated with anxiety \& depression, and if those affects are moderated by work qualities. It was also attempted to reveal the variation among those patterns by gender. It is also found that in more noxious work environment, the relationship is stronger and positive between home to work conflict and depression for men. The study also shows that work-to-home conflict has a stronger effect on anxiety than has home-to-work. Lingard \& Lin (2004) explored the relationship between organizational commitment (OC) and its determinants being job career, family, and work setting variables among women in Australian construction industry. Organizational commitment is significantly related to the variables understudy, including satisfaction with career progression, job involvement, career choice commitment, supervisory support and perception of the organizational diversity climate. There was no evidence of any demographic or family variable being correlated with OC. The study also suggests that OC doesn't differ significantly for women, with or without children. Hence, it suggests that such organizations should make sure that women have access to career development opportunities and their processes for reward allocation are fair. Lambert et al. (2006) studied the impact of work-life conflict on employees' job satisfaction and organizational commitment using OLS regression for social and human service workers. It reveals that time-based conflict tends to be highest followed by work-role behavior, strain-based, and then family-role behavior conflict. Work-role behavior conflict also significantly affects job satisfaction and organizational commitment. Mohamed et al. (2006) studied the relationship between employee organizational commitment, intend to quit, and environment. There exists a negative relationship between affective commitment and 
intend to quit, and a positive relationship between supportive environment and affective organizational commitment. Scandura \& Lankau (1997) studied a matched sample of male and female managers and revealed that women in those organizations which offer flexible work hours show greater level of organizational commitment and job satisfaction than those who are not offered such benefit. Study also shows that women with families show higher organizational commitment when offered flexible work hours. Chiu \& $\mathrm{Ng}$ (2001) examined the impact of work oriented and family-oriented women friendly policies on their job and organizational behavior. It is observed that single female employees show higher affective commitment in the presence of work-oriented policies whereas presence of family-oriented policies showed positive association with continuance commitment. Hence, the study suggests examining the demographics of workforce for development of effective HR policies for working women.

\section{National Perspective}

Bashir \& Ramay (2008) investigated the relationship between career opportunities, worklife policies job characteristics and organizational commitment among IT professionals in public and private sectors. The study indicated a significant positive relationship between career opportunities, work-life policies and organizational commitment but no significant relationship between job characteristics and organizational commitment was found. Age and tenure showed weak and insignificant relationship with organizational commitment. Nadeem \& Abbas (2009) observed the association among work-life conflicts and job satisfaction of employees in Pakistan. The findings depict that there exists a negative relationship between stress and job satisfaction and between work to family interference, family to work interference and Job satisfaction. However, workload is positively but insignificantly linked to JS, suggesting that that workload doesn't affect Job satisfaction of employees in Pakistan. Khan et al. (2010) investigates the association between organizational commitment and employee Job performance. Study revealed that commitment has significant effect on job performance. The study also reveals that males are higher performers' vis-a-vis female in Pakistan's private sector. Malik et al. (2010) examines to what extend teachers in public universities are satisfied with their jobs and committed to their universities. The study indicates that university teachers are highly satisfied with their job dimensions (salary, coworkers, quality of supervision, opportunities for promotion, etc.). It is concluded from the findings that significant predictors of organizational commitment in Pakistani public universities include nature of work, quality supervision and salary satisfaction. The study suggests that to make employees highly committed and satisfied, organizations should provide intrinsic and extrinsic job rewards. The findings of Abdullah and Ramay (2012) revealed that employees with higher tenure and age show greater organizational commitment. The study of Ahmad et al. (2011) shows that the effect of conflicts arising from work-life balance has severe mental and physical consequences for working women. The study by 
Alam et al.(2011) suggested that there might be other factors such as job satisfaction, organizational commitment and organizational citizenship behavior which might have significant relationship with work-life conflicts. Literature also shows that there exists no significant difference between male and female employees in terms of their work-life conflicts (Chaudhry et al., 2011). Rehman \& Waheed (2012) inspected the impact of work-family conflict on organizational commitment among faculty members in private and public universities of Pakistan. ANOVA results revealed that compared to single, married teachers had high work-family conflict. In respect to work-family conflict among male and female employees no significant differences found. Another study was conducted by Saher et al. (2013) which concluded that working women, despite having work-life conflicts, are successful in managing it. However, a study by Batool \& Raza (2013) revealed that there is a significant negative relationship between job stress and organizational commitment. However, the relationship between job stress and affective commitment is very weak and statistically insignificant. There is no relationship between job stress and normative commitment and there is insignificant relationship between job stress and continuance commitment. The thorough review of literature reveals that women face different problems due to their dual commitment in balancing work and life. However, as far as the effect of problems on organizational commitment is concerned, it showed mixed results. These results cannot be generalized for every country, industry, or organization. The literature review also identifies different predictors of work-life conflicts and organizational commitment. Hence, there exists a strong need to conduct country-specific and industry-specific research to explore relationships between the main variables i.e. work-life conflict and organizational commitment. Review also indicated that much research has not been done on the two variables.

\section{Hypotheses}

$\mathbf{H}_{1}$ : Time based conflict has significant effect on women employee affective commitment in private universities of Pakistan

$\mathbf{H}_{2}$ : Time based conflict has significant effect on women employee continuance commitment in private universities of Pakistan

$\mathbf{H}_{3}$ : Time based conflict has significant effect on women employee normative commitment in private universities of Pakistan

$\mathbf{H}_{4}$ : Strain based conflict has significant effect on women employee affective commitment in private universities of Pakistan

H5: Strain based conflict has significant effect on women employee continuance commitment in private universities of Pakistan

$\mathbf{H}_{6}$ : Family based conflict has significant effect on women employee normative commitment in private universities of Pakistan

$\mathbf{H}_{7}$ : Behavior based conflict has significant effect on women normative employee commitment in private universities of Pakistan 
$\mathbf{H}_{8}$ : Behavior based conflict has significant effect on women affective employee commitment in private universities of Pakistan

$\mathbf{H}_{9}$ : Behavior based conflict has significant effect on women continuance employee commitment in private universities of Pakistan

Figure 2.1 Conceptual Framework

\section{Dependent Variables Independent variables}

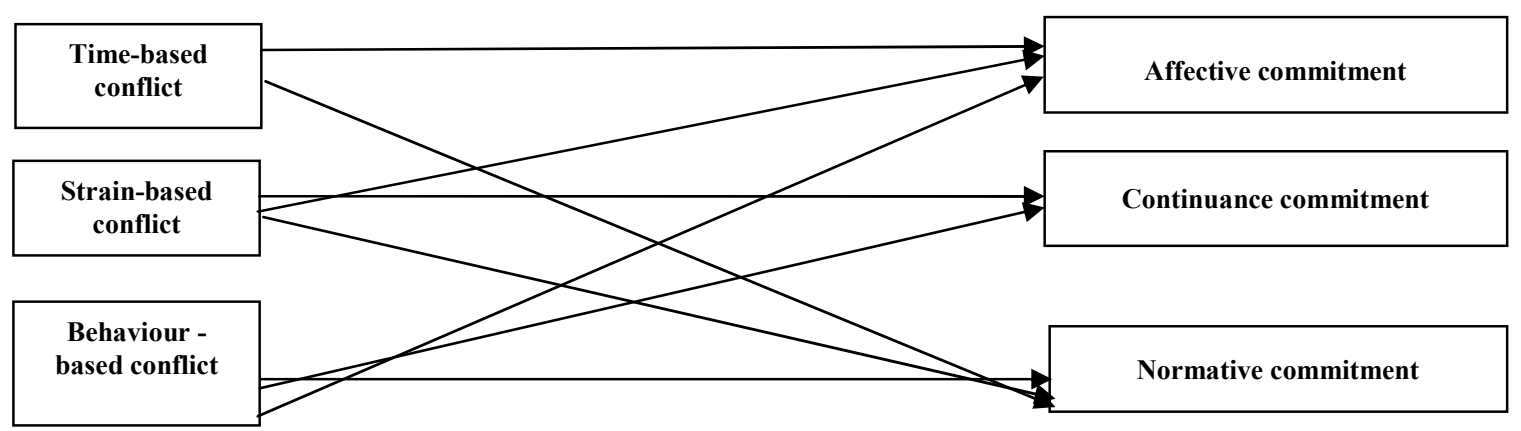

\section{Research Methodology}

It is a descriptive, quantitative and cross-sectional study. The reason for selecting quantitative research design was to present the data numerically for the purpose of statistically describing the data gathered. Quantitative research design is suitable for testing of hypothesis, as we wanted to explain whether there is an association between work-life conflicts and organizational commitment. Two focus group interviews were conducted at a private university to identify the reasons behind the results obtained through survey. A questionnaire was designed, and the data was collected in five months starting from Nov 2012 till March 2013 targeting 20 private business universities based in Karachi. A total of 200 questionnaires were distributed in the private universities of Karachi, out of which 127 questionnaires were received, having a response rate of 63.5 percent. ${ }^{1}$ Three types of organizational commitment ("affective commitment, continuance commitment and normative commitment") were studied; each type was measured through 6 questions in this section. It was developed using revised organizational commitment scale developed by Allen and Meyer (1991). Allen and Mayer's organizational commitment questionnaire has become a widely used instrument to measure the three types of organizational commitment, namely affective, continuance and normative organizational commitment (Smeenk et al. 2006). The second section measured work-life conflicts among permanent female faculty at business universities in Karachi. Three types of work-life conflicts ("time-based conflict, strain-based conflict and behavior-based conflict") were measured through the use of 9 items in this section. Each type of conflict was measured by the use of 3 items. It was developed using Carlson et al. (2000) Scale. Third section was designed to identify the 
demographic variables of the respondents consisting of ten items, including marital status, family system, age, academic degree acquired, organization, designation, tenure with the organization and description about children, if any. Permission was requested from the concerned authorities at all targeted universities. 15 of the 20 universities granted the permission to collect the data from their universities. Using personal references, resource persons were identified at each university who helped in getting the questionnaires filled at their respective campuses. An average of three visits were made at almost all universities. Normality of the data was checked for the constructs with the help of PP plot, histogram and measures of shapes which are namely Skewness and Kurtosis. Data was entered in Statistical Package for Social Sciences (SPSS), version 16.0 and then statistically analyzed. Correlation was used to check the association between two variables. The results were further corroborated by the use of contingency table. T-test of correlation and chi-square test of association were utilized. Multi-item scale was tested for the consistency of items through Cronbach alpha. Mean and standard deviation were used for quantitative data.

\section{Statistical Analysis}

The Cronbach alpha level for affective commitment as shown in Table- 1 was 0.88 , for continuance commitment it is 0.68 and for normative commitment the level is 0.73 . All the constructs are having the Cronbach alpha more than 0.65 , showing that all the constructs have inter-item consistency.

There were 66 (52 percent) of respondents who were married and 61 (48 percent) of the respondents were unmarried. 53\% of married respondents lives in joint family system and $47 \%$ of married respondents lives in nuclear family system. 106 (83.4 percent) respondents had a Masters degree, 12 (9.45 percent) respondents had M-Phil/MS degree and 9 (7.09 percent) had $\mathrm{PhD}$ degree. Respondents working as lecturer in private universities were 94 (74.02 percent) of the total respondents, 30 (23.62 percent) were working as assistant professors and 3 (2.36 percent) were working as associate professors in private business universities in Karachi.

Table: 1

Cronbach alpha coefficient of organizational commitment scales

\begin{tabular}{|l|c|c|c|}
\hline \multicolumn{1}{|c|}{ Construct } & Cronbach's Alpha & No. of Items & Scale \\
\hline Affective Commitment & 0.88 & 6 & $1-5$ \\
\hline Continuance Commitment & 0.68 & 6 & $1-5$ \\
\hline Normative Commitment & 0.73 & 6 & $1-5$ \\
\hline
\end{tabular}

The level of Cronbach alpha for Time-based conflict is 0.69 as reflected in Table- 2 . The level of Cronbach alpha for Strain-based conflict is 0.86 and the Cronbach alpha for Behavior-based conflict is 0.62 showing that all the constructs have inter-item consistency. 
Table: 2

Cronbach alpha coefficient of work-life conflict scales

\begin{tabular}{|l|c|c|c|}
\hline Construct & Cronbach's Alpha & No. of Items & Scale \\
\hline Time-based Conflict & 0.69 & 3 & $1-5$ \\
\hline Strain-based Conflict & 0.86 & 3 & $1-5$ \\
\hline Behavior-based Conflict & 0.62 & 3 & $1-5$ \\
\hline
\end{tabular}

The correlation matrix presented in Table- 3 shows that time-based conflict has a weak negative relationship with affective commitment (- 0.097) and normative commitment ($0.08)$, whereas it has a weak positive relationship with continuance commitment (0.073). Strain-based conflict has a weak negative relationship with affective commitment and continuance commitment $(-0.061$ and -0.071$)$ and had a weak positive relationship with normative commitment (0.05). Behavior-based conflict has a weak negative relationship with affective commitment (-0.098) and normative commitment (-0.06) and a weak positive relationship with continuance commitment $(0.071)$.

\section{Table: 3}

Correlation matrix for Organizational Commitment and Work-Life conflict

\begin{tabular}{|l|l|r|r|r|r|r|}
\hline Variables & $\mathbf{2}$ & $\mathbf{3}$ & $\mathbf{4}$ & $\mathbf{5}$ & $\mathbf{6}$ \\
\hline \multirow{2}{*}{$\begin{array}{l}\text { Behavior-based } \\
\text { conflict (1) }\end{array}$} & Pearson Correlation & 0.293 & 0.365 & -0.098 & 0.071 & -0.06 \\
\cline { 2 - 6 } $\begin{array}{l}\text { Time-based } \\
\text { conflict (2) }\end{array}$ & Sig. (1-tailed) & 0 & 0 & 0.137 & 0.212 & 0.264 \\
\hline \multirow{2}{*}{$\begin{array}{l}\text { Strain-based } \\
\text { conflict (3) }\end{array}$} & Pearson Correlation & 1 & 0.599 & -0.097 & 0.073 & -0.08 \\
\cline { 2 - 6 } & Sig. (1-tailed) & & 0 & 0.14 & 0.209 & 0.183 \\
\hline $\begin{array}{l}\text { Affective } \\
\text { Commitment (4) }\end{array}$ & Pearson Correlation & & 1 & -0.061 & -0.071 & 0.05 \\
\cline { 2 - 7 } $\begin{array}{l}\text { Continuance } \\
\text { Commitment (5) }\end{array}$ & Sig. (1-tailed) & & & 0.247 & 0.214 & 0.271 \\
\hline \multirow{2}{*}{$\begin{array}{l}\text { Normative } \\
\text { Commitment (6) }\end{array}$} & Pearson Correlation & & & 1 & 0.061 & 0.49 \\
\cline { 2 - 7 } & Sig. (1-tailed) & & & & 0.246 & 0 \\
\cline { 2 - 7 } & Sig. (1-tailed) & & & & & 0.02 \\
\cline { 2 - 7 } & Pearson Correlation & & & & & 1 \\
\hline
\end{tabular}

**. Correlation is significant at the 0.01 level (1-tailed).

The same reality was tested using chi-square. Data was converted into dichotomous (agree and disagree). The variables were found not to be associated with each other. Association between time-based conflict and affective commitment was checked through chi-square. They were found not to be associated at $5 \%$ significance level ( $(\mathrm{P}(0.247)>$ $0.05(\alpha))$. Correlation between Time-based conflict and continuance commitment was tested using chi-square, which explores no association between the said variables. At5\% significance level, they were found not to be associated $(\mathrm{P}(0.715)>0.05(\alpha))$. Time-based 
conflict and normative commitment were also not associated when tested using chisquare at $5 \%$ significance level $(\mathrm{P}(0.347)>0.05(\alpha))$. At $5 \%$ significance level Strainbased conflict and affective commitment were found not to be associated with each other using chi-square $(\mathrm{P}(0.351)>0.05(\alpha))$. Strain-based conflict and continuance commitment were also tested through chi-square and found not to be associated with each other at $5 \%$ significance level $(\mathrm{P}(0.752)>0.05(\alpha))$. Strain-based conflict and normative commitment were not associated at $5 \%$ significance level of $5 \%(\mathrm{P}(0.874)>0.05(\alpha))$. Association between Behavior-based conflict and affective commitment when tested through chisquare revealed that there exists no relationship among them at $5 \%$ significance level (P $(0.496)>0.05(\alpha))$. There exist no association between Behavior based conflict and continuance commitment when tested through chi-square at $5 \%$ significance level (P $(0.326)>0.05(\alpha)$ ). Association between Behavior based conflict and normative commitment was also tested using chi-square but exposed no association between them at $5 \%$ significance level $(\mathrm{P}(0.257)>0.05(\alpha))$.

\section{Results and Discussion}

It was expected that working women would be experiencing different types of conflicts, particularly time-based and stress-based conflicts, as they have less time for children and undergo physical and mental stress due work overload (London et al. 2004). These conflicts were assumed to have a negative effect on employees' commitment types discussed here. However, the results achieved are different for this study. The study reveals that majority of female faculty has continuance commitment. As many of our respondents comprised of married women this might concur with the previous literature showing that working women wife's increasing income increases the likelihood of a happy married life and their well-being (Rogers \& DeBoer, 2001). The same is further corroborated with the fact that working women increase income of family, social ties, independence feeling and high self-esteem and self-sufficiency values for their children (London et al. 2004). It is also revealed that these working women trade off their time between weekdays and weekends, as working mothers spend more time with their children on weekends than mothers at home (Booth et al. 2002). It has been revealed during the study that female faculty at private universities have affective, continuance and normative commitment. This result is not as expected. It was assumed that working women in private universities do not show such commitments with their organization, but the unusual results suggest that one reason might be that these working women have some help at their homes which helps in continuance commitment. This is keeping with the Sasaki (2002) study which says that employed women are more educated and are more likely to co-reside than full-time housewives. However, Ritcher (1996) suggests that living separately is more closely related to women's job status. The study reveals that female faculty with children shows higher affective and normative commitment. 
This result is supported with the study that women with families show higher organizational commitment when offered flexible work hours (Scandura \& Lankau, 1997). However, it contradicts with Lingard \& Lin (2004) saying that demographic variable doesn't show any evidence of correlation with organizational commitment and so it does not differ significantly for women with or without children. Faculty living in joint families faces all types of conflicts and their conflicts are higher than those living in nuclear families. They possess both time-based and strain-based conflicts. It is supported by Lambert et al. (2006) that time-based conflict tends to be the highest followed by strain-based conflict. They show higher affective commitment; the reason can be the supporting environment, as employees feel obliged to somehow return for the support and hence show their affection with their organization (Mohamed et al. 2006). A strong reason of having organizational commitment might be flexible work hours and relaxed environment in universities as compared to the corporate world. Employees show greater level of organizational commitment and job satisfaction than those who are not offered such benefits (Scandura \& Lankau 1997). The results suggest that unmarried faculty have more affective and normative commitment in contrast to married faculty members. However, this contradicts with some studies as single female employees show higher affective commitment in the presence of work-oriented policies whereas presence of family oriented policies showed positive association with continuance commitment (Chiu \& Ng, 2001). Study indicates that female faculty bearing no children has more time-based conflicts as compared to those bearing children. This contradicts the previous study highlighting that parents had greater workfamily conflicts than non-parents (Bragger et al. 2005). One reason for this can be that those faculty bearing no children are more career-focused and into acquiring their professional qualification; hence, they show time-based conflict, as in universities achieving higher education is becoming extremely critical. However, the difference between their responses is negligible.

\section{Conclusions}

The exhaustive study is an attempt to contribute to the existing literature on work-life conflicts and organizational commitment. The study reveals that faculty at private universities have mainly time-based conflict whereas they have almost negligible strain-based and behavior-based conflict. Through focus group interviews, it has been revealed that female faculty at private universities have affective, continuance and normative commitment. It has been observed that the mean value of the construct measuring organizational commitment clearly shows that affective commitment is highest in contrast to continuance and normative commitment among female faculty. The prime reason of affective commitment being highest in contrast to their 
continuance and normative commitment is relaxed work environment in the education sector. The interview also unveils that majority of female faculty has continuance commitment and its reason is high inflation that makes essential for both the educated partners to work for bearing the high cost of living. Female faculty shows a normative commitment with their organization that satisfies their social need. By socializing with their colleagues at universities, they form a special kind of bonding with them at work and share their joys and sorrows with each other. Unmarried faculty has more affective and normative commitment in contrast to married faculty members; however, continuance commitment remains same for both groups. Affective commitment of employees increases with the increase in number of years spent in organization. However, the time-based conflict decreases while behavior-based conflict increases with the increase in tenure spent at organizations. Results also show that with increasing age, affective commitment increases while behavior-based conflict decreases. It has also been explored that faculty in the highest age category has the highest level of continuance commitment. Studies indicate that there exists a positive relationship between age and organizational commitment (Banai \& Reisel 1993; Jans, 1989). In terms of educational qualifications of female faculty it is noticed that those with highest level of education (Ph.D) do not possess any type of conflicts and they have the highest level of affective as well as normative commitment. Those who have earned Masters degrees have the highest level of continuance commitment. Female faculty with children shows higher affective and normative commitment. Faculty living in joint families possesses all types of conflicts and their conflicts are higher than those living in nuclear families. Affective, continuance and normative commitment increases with higher designations. Work-life conflicts when tested among faculty members at different designations showed that those who are working at lower designations have time-based and strain-based conflicts, but these conflicts decline at higher levels.

\section{Recommendations and Future Directions}

Universities should come up with policies offering flexible working hours to overcome time-based conflict. Further studies should be carried out to find out the relationship between the said variables in terms of gender. Research is to be carried out to find out the relationship between said variables at different industries throughout the city and country. Such studies will indicate the conflict types among employees in all fields across country. Comparative studies can be conducted to test the conflict types and commitment levels of employees working in different departments within and across different organizations. To study if work-life conflicts and organizational commitment changes with increase of age, designation, degrees earned and other personal characteristics, longitudinal studies must be carried out. To support the results of this study and for an in-depth reasoning of the findings, qualitative studies can be carried out. 


\section{End Notes}

1. Higher Education Commission (HEC) recognized 20 private management science universities were targeted, however respondents from 15 universities' permanent female faculty members filled and returned the questionnaires. Assuming the population was around 200, our sample size was 127 which is 63.5 percent of the total population.

\section{References}

Abdullah \& Ramay, M.I. (2012). Antecedents of Organizational Commitment of Banking Sector Employees in Pakistan. Serbian Journal of Management, vol.7:1, pp.89-102.

Ahmad, M. S., Fakhr, Z. \& Ahmed, J. (2011). Working Women Work-Life Conflict. Business Strategy Series, vol.12:6, pp.289-302.

Alam, R., Shumaila, S., Azhar, M. \& Sadaqat, S. (2011). Work-Family Conflicts: Relationship between Work-Life Conflict and Employee Retention - A Comparative Study of Public and Private Sector Employees. Interdisciplinary Journal of Research in Business, vol.1:2, pp.18-29.

Allen, N. \& Meyer, J. (1990). The Measurement and Antecedents of Affective, Continuance and Normative Commitment to the Organization. Journal of Occupational Psychology, vol.63:1, pp.1-18.

Allen, N. \& Meyer, J. (1991). A Three-Component Conceptualization of Organizational Commitment. Human Resource Management Review, vol.1, pp.61-89.

Banai, M. \& Reisel, W.D. (1993). Expatriate Managers' Loyalty to the MNC: Myth or Reality? An Exploratory Study. Journal of International Business Studies, vol.24:2, pp.233-248.

Bashir, S. \& Ramay, M.I. (2008). Determinants of Organizational Commitment: A Study of Information Technology Professionals in Pakistan. Journal of Behavioral and Applied Management, vol.9:2, pp.226-238.

Batool, M. \& Razaullah (2013). Impact of Job Satisfaction on Organizational Commitment in Banking Sector: Study of Commercial Banks in District Peshawar. International Review of Basic and Applied Sciences, vol.1:2, pp.12-24. 
Baughman, R., DiNardi, D. \& Holtz-Eakin, D. (2003). Productivity and Wage Effects of "Family-Friendly" Fringe Benefits, International Journal of Manpower, vol.24:3, pp.247-259.

Bhagat, R. S. \& Chassie, M. B. (1981). Determinants of Organizational Commitment in Working Women: Some Implications for Organizational Integration, Journal of Organizational Behavior, vol.2, pp.17-30.

Booth, C. L., K. A. Clarke-Stewart, D. L. Vandell, K. McCartney, \& M. T. Owen. (2002). Child-care Usage and Mother-infant 'Quality Time'. Journal of Marriage and Family, vol.64, pp.16-26.

Bragger, D. B., Rodriguez-Srednicki, O., Kutcher, E. J., Indovino, L. \& Rosner, E. (2005). Work-Family Conflict, Work-Family Culture and Organizational Citizenship Behavior among Teachers. Journal of Business and Psychology, vol.20:2, pp.303-324.

Browne, K. R. (1998). An Evolutionary Account of Women's Workplace Status, Managerial and Decision Economics. Management, Organization and Human Nature, vol.19:7/8, pp.427-440.

Bruke, R.J. \& Bradshaw, P. (1981). Occupational and Life Stress and the Family. Small Group Behavior, vol.1:12, pp.320-375.

Burke, R.L., Weir, T. \& Duwors, R.E. (1980). Work Demands on Administrators and Spouse Well-Being. Human Relations, vol.33, pp.253-278.

Carlson, D.S., Kacmar, K. M. \& Williams, L. J. (2000). Construction and Validation of a Multidimentional Measure of Work-Life Conflict. Journal of Vocational Behavior, vol.56:2, pp.249-276.

Chaudhry, A. A., Malik, M. I. \& Ahmad, I. (2011). Examining the Relationship of WorkLife Conflict and Employee Performance (A Case from NADRA Pakistan). International Journal of Business and Management, vol.6:10, pp.170-177.

Chughtai, A. A. \& Zafar, S. (2006). Antecedents and Consequences of Organizational Commitment among Pakistani University Teachers. Applied H.R.M. Research, vol.11:1, pp.39-64. 
Cockrum, J. \& White, P. (1985). Influences on the Life Satisfaction of Never-Married Men and Women. National Council on Family Relations, vol.34:4, pp.551-556.

Demo, D. H. \& Acock, A.C. (1993). Family Diversity and the Division of Domestic Labor: How Much Things Have Really Changed? Family Relations, vol.42, pp.323-331.

Dessler, G. \& Varkkey, B. (2009). Human Resource Management, Pearson/Prentice Hall, India, pp.535-538.

Eiswirth-Neems, N.A. \& Handal, P.J. (1978). Spouse's Attitudes towards Maternal Occupational Status and Effects on Family Climate. Journal of Community Psychology, vol.6, pp.168-172.

Geisel, R., (2004). Responding to Changing Ideas of Family. HR Magazine, pp.89-98.

Greenhaus, J. H. \& Beutell, N. J. (1985). Sources of Conflicts between Work and Family Roles. The Academy of Management Review, vol.10:1, pp.76- 88.

Greenhaus, J.H. \& Parasuraman, S. (1997). Research on Work, Family and Gender: Current Status and Future Directions. Handbook of Gender and Work, pp.391-412.

Greenhaus, J.H. \& Kopelman, R.E.(1981). Conflict between Work and Nonwork Roles: Implications for the Career Planning Process, Journal of Human Resource Planning, vol.4:1, pp.1-10.

Chiu, W. C. \& Ng, C. W. (2001). The Differential Effects of Work-and Family-Oriented Women-Friendly HRM on OC and OCB: The Case for Single Female Employees in Hong Kong. International Journal of Human Resource Management, vol.12:8, pp.1347-1364.

Hall, D. T. \& Gordon, F. E. (1973). Career Choices of Married Women: Effects on Conflicts, Role behavior and Satisfaction. Journal of Applied Psychology, vol.58, pp.42-48.

Hannay, M. \& Northam, M. (2000). Low-Cost Strategies for Employee Retention. Compensation and Benefits Review, pp.65-72.

Herman, J.B. \& Gyllstrom, K.K. (1977). Working Men and Women: Inter- and Intra-Role Conflict, Psychology of Women Quarterly, vol.1, pp.319-333.

Jans, N.A. (1989). Organizational Commitment, Career Factors and Career/ Life Stage. Journal of Organizational Behavior, vol.10:3, pp.247-266. 
Jones, A.P. \& Butler, M.C. (1980). A Role Transition Approach to the Stresses of Organizationally-Induced Family Role Disruption. Journal of Marriage and the Family, vol.42, pp.367-376.

Judge, T.A., IIies, R. \& Scott, B.A. (2006). Work-Family Conflict and Emotion: Effects at Work and Home. Personnel Psychology, vol.59, pp.779- 814.

Khalili, A., Asmawi, A. (2012). Appraising the Impact of Gender Differences on Organizational Commitment: Empirical Evidence from a Private SME in Iran. International Journal of Business and Management, vol.7:5, pp.100-110.

Khan, M.H., Ziauddin, Jam,F.A. \& Ramay, M.I. (2010). The Impact of Organizational Commitment on Employee Job Performance. European Journal of Social Sciences, vol.15:3, pp.292-298.

Konrad, A.K. \& Mangel, R. (2000). The Impact of Work-Life Programs on Firm Productivity. Strategic Management Journal, vol.21:12, pp.1225-1237.

Lambert, E. G., Pasupuleti, S., Clusetolar, T., Jennings, M. \& Baker, D. (2006). The Impact of Work- Family Conflict on Social Work and Human Service Worker Job Satisfaction and OC. Administration in Social Work, vol.30:3, pp.55-74.

Lambert, S. (2000). Added Benefits: The Link between Work-Life Benefits and Organizational Citizenship Behavior. Academy of Management Journal, vol.43:5, pp.801-815.

Lamsa, A. M. \& Sintonen, T. A. (2001). Discursive Approach to Understanding Women Leaders in Working Life. Journal of Business Ethics, vol.34:3/4, pp.255-267.

Lingard, H. \& Lin, J. (2004). Career, Family and Work Environment Determinants of Organizational Commitment among Women in the Australian Construction Industry. Construction Management \& Economics, vol.22:4, pp.409-420.

London, S. A., Scott, E. K., Edin, K. \& Hunter, V. (2004). Welfare Reform, Work-Family Tradeoffs and Child Well-Being. Family Relations, vol.53:2, pp.148-158.

MacDermid, S.M., Williams, M., Marks, S. \& Heilbrun, G. (1994). Is small beautiful? Work-Family Tension, Work Conditions and Organizational Size. Family Relations, vol.43:2, pp.159-167. 
Makela, L. (2005). Pregnancy and Leader-Follower Dyadic Relationships: A Research Agenda. Equal Opportunities International, vol.24:3, pp.50-72.

Malik, M.E., Nawab, S., Naeem, B. \& Danish, R.Q. (2010). Job Satisfaction and Organizational Commitment of University Teachers in Public Sector of Pakistan. International Journal of Business and Management, vol.5:6, pp.17-26.

Menaghan, \& Elizabeth, G. (1989). Role Changes and Psychological Well-Being: Variations in Effects by Gender and Role Repertoire. Social Forces, vol.67, pp.693-714.

Mohamed, F., Taylor, G.S. \& Hassan, A. (2006). Affective Commitment and Intend to Quit: The Impact of Work and Non-Work-Related Issues. Journal of managerial Issues, vol.18:4, pp.512-529.

Nadeem, M.S. \& Abbas, Q. (2009). The Impact of Work Life Conflict on Job Satisfactions of Employees in Pakistan. International Journal of Business and Management, vol.4:5, pp.63-83.

Netemeyer, R. G., Boles, J. S. \& McMurrian, R. (1996). Development and Validation of Work-Family Conflict and Family-Work Conflict Scales. Journal of Applied Psychology, vol.81, pp.400-410.

Pleck, J.H., Staines, G.L. \& Lang, L. (1980). Conflicts between Work and Family Life. Monthly Labor Review, vol.103:3, pp.29-32.

Rehman, R.R. \& Waheed, A. (2012). Work-Life Conflicts and Organizational Commitment: Study of Faculty Members in Pakistani Universities. Pakistan Journal of Social and Clinical Psychology, vol.10:1, pp.23-26.

Richter, K. (1996). Living Separately as a Child-Care Strategy: Implications for Women's Work and Family in Urban Thailand. Journal of Marriage and Family, vol.58:2, pp.327-339.

Rogers, S. J. \& DeBoer, D.D. (2001). Effects on Marital Happiness, Psychological WellBeing and the Risk of Divorce. Journal of Marriage and Family, vol.63:2, pp.458-472.

Saher, N., Matloob, T., Tahreen, F., Ali, S.S. \& Al Sulim, G.H. (2013). Work-Family Conflict in Pakistan: Juggling of Activities on Personal Values and Commitments. Middle East J. Management, vol.1:1, pp.28-48. 
Sanders, M.R., Haslam, D. M., Calam, R., Southwell, C. \& Stallman, H. M. (2011). Designing Effective Interventions for Working Parents: A Web-Based Survey of Parents in the UK Workforce. Journal of Children's Services, vol.6:3, pp.186-200.

Sasaki, M. (2002). The Causal Effect of family Structure on Labor Force Participation among Japanese Married Women. The Journal of Human Resources, vol.37:2, pp.429-440.

Scandura, T.A. \& Lankau, M.J. (1997). Relationships of Gender, Family Responsibility and Flexible Work Hours to Organizational Commitment and Job Satisfaction. Journal of Organizational Behavior, vol.18:4, pp.377-391.

Schieman, S., McBrier, D.B. \& Gundy. K.V. (2003). Home-to-Work Conflict, Work Qualities and Emotional Distress. Sociological Forum, vol.18:1, pp.137-164.

Secret, M. (2000). Identifying the Family, Job and Workplace Characteristics of Employees Who Use Work Family Benefits. Family Relations, vol.49:2, pp.217-225.

Silver \& Cynthia (2000). Being There: The Time Dual-Earner Couples Spend with their Children. Canadian Social Trends, vol.11:8, pp.26-29.

Smeenk, S.G.A., Eisinga, R.N., Teelken, J.C. \& Doorewaard, J.A.C.M. (2006). The Effects of HRM Practices and Antecedents on Organizational Commitment among University Employees. The International Journal of Human Resource Management, vol.17:12, pp.2035-2054.

Parasuraman, S., Greenhaus, J. H. \& Linnehan, F. (2000). Time, Person-Career Fit and the Boundaryless Career. Trends in Organizational Behavior, vol.7, pp.63-78.

Igbaria, M., Greenhaus, J. H. \& Parasuraman, S. (1991). Career Orientations of MIS Employees: An Empirical Analysis. MIS Quarterly, pp.151-169.

Stewart, S.M., Bing, M.N., Gruys, M.L. \& Helford, M.C. (2007). Men, Women and Perceptions of Work Environments, Organizational Commitment, and Turnover. Journal of Business and Public Affairs, vol.1:1.

Tausig \& Mark. (1999). Work and Mental Health. Handbook of the Sociology of Mental Health, pp.255-276. 
Trovato, F. \& Vos, R. (1992). Married Labor Force Participation and Suicide in Canada. 1971 and 1981. Sociological Forum, vol.7:4, pp.661-677.

Wentling, R. M., (1996). A Study of Career Development and Aspirations of Women in Middle Management. Human Resource Development Quarterly, vol.7, pp.253-270.

Sobia Shujaat is an Assistant Professor in the Department of Management Sciences, Bahria University, Islamabad.

Iram Tahir is Ph.D Scholar in the Department of Public Administration, University of Karachi.

Dr. Akhtar Baloch is Vice Chancellor of Benazir Bhutto Shaheed University, Karachi. 